\title{
Implementasi Nilai-Nilai Pendidikan Pancasila pada Sekolah Tinggi Keguruan dan Ilmu Pendidikan (STKIP) Bima
}

\author{
Yasser Arafat \\ STKIP Bima, Kota Bima, Indonesia \\ *Coresponding Author : yasserarafat003@gmail.com \\ Dikirim: 12-08-2021 ; Direvisi: 18-08-2021 ; Diterima: 19-08-2021
}

\begin{abstract}
Abstrak: Tujuan penelitian ini adalah untuk mengetahui implementasi nilai-nilai pendidikan Pancasila pada kegiatan kurikuler, kokurikuler dan ekstra kurikuler di Sekolah Tinggi Keguruan dan Ilmu Pendidikan (STKIP) Bima, dengan mempelajari dan mengkaji muatan materi kurikulum pembelajaran maupun dokumen-dokumen pendukung kegiatan kegiatan kokurikuler dan ekstra kurikuler yang ada, apakah-dokumen tersebut memuat secara konsisten materi-materi penguatan nilai-nilai pendidikan Pancasila sesuai dengan tujuan pembelajaran pendidikan Pancasila yaitu untuk menghasilkan mahasiswa Indonesia yang beriman dan bertakwa kepada Tuhan Yang Maha Esa dengan sikap dan perilaku, yaitu memiliki kemampuan untuk mengambil sikap yang bertanggung jawab, memiliki kemampuan untuk mengenali perkembangan ilmu pengetahuan dan teknologi, dan memiliki kemampuan sikap untuk menggalang persatuan. Penelitian ini merupakan library research yaitu penelitian kepustakaan. Adapun jenis data adalah data sekunder. Teknik pengambilan data dilakukan studi literatur atau analisis dokumen. Penelitian ini menggunakan pendekatan penelitian kualitatif secara deskriptif dengan menerapkan teknik studi dokumentasi. Analisis data hasil penelitian ini dilakukan secara kualitatif yaitu menguraikan data secara deskriptif berdasarkan fakta-fakta yang ada. Adapun implementasi nilai-nilai pendidikan pancasila di STKIP Bima dilaksanakan melalui kegiatan kurikuler, kokurikuler dan ekstrakurikuler.
\end{abstract}

Kata Kunci: Implementasi nilai Pancasila; Pendidikan Pancasila

Abstract: The purpose of this study was to determine the implementation of Pancasila educational values in curricular, co-curricular and extra-curricular activities at the Bima Teacher Training and Education School (STKIP), by studying and reviewing the content of learning curriculum materials and supporting documents for co-curricular activities. and extra-curricular activities that exist, do these documents consistently contain materials for strengthening the values of Pancasila education in accordance with the learning objectives of Pancasila education, namely to produce Indonesian students who believe and fear God Almighty with attitudes and behavior, namely having the ability to to take a responsible attitude, have the ability to recognize the development of science and technology, and have the attitude ability to build unity. This research is library research, namely library research. The type of data is secondary data. The technique of collecting data is literature study or document analysis. This study uses a descriptive qualitative research approach by applying documentation study techniques. Data analysis of the results of this study was carried out qualitatively, namely describing the data descriptively based on the existing facts. The implementation of Pancasila educational values at STKIP Bima is carried out through curricular, co-curricular and extracurricular activities.

Keywords: Implementation of Pancasila values; Pancasila Education

\section{PENDAHULUAN}

Kebijakan pendidikan nasional merupakan kebijakan pendidikan yang diarahkan untuk pembangunan manusia Indonesia seutuhnya, salah satu amanat 
pendidikan yang menjadi tugas penting Negara sebagaimana termaktub dalam pembukaan Undang-Undang Dasar 1945 yaitu mencerdaskan kehidupan bangsa, yang ditandai berkembangnya potensi peserta didik agar menjadi manusia yang beriman dan bertakwa kepada Tuhan Yang Maha Esa, berakhlak mulia, sehat, berilmu, cakap, kreatif, mandiri, dan menjadi warga Negara yang demokratis dan bertanggung jawab (UU Sisdiknas Nomor 20 Tahun 2003). Mencerdaskan kehidupan bangsa bermakna bahwa pendidikan nasional harus dilakukan secara menyeluruh pada semua kalangan, tanpa memandang status, golongan, etnis, ras, dan agama dijadikan sebagai konstruksi pembangunan bangsa, sehingga dampak dari pendidikan mempengaruhi kemajuan di bidang pembangunan lainnya, seperti ekonomi, sosial, budaya dan politik (Andang, 2014:24).

Pendidikan nasional diarahkan untuk menyiapkan generasi yang memiliki mental kepribadian yang agamis, toleran, berbudaya dan berdaya saing sebagaimana dicita-citakan oleh pancasila sebagai dasar negara. Bangsa Indonesia sebagai bangsa yang plural tentu memiliki tantangan yang besar dalam menghadapi gelombang perubahan sosial, ekonomi, dan politik akibat semakin terbukanya koneksi dan inter relasi hubungan diplomatik antara negara yang saling memberi pengaruh bagi perkembangan pendidikan suatu Negara. Di era digital keterbukaan informasi dapat dimanfaatkan sebagai upaya meningkatkan daya saing bangsa melalui penerapan kebijakan pendidikan yang bermutu, konsisten yang terintegrasi dengan kebutuhan kemajuan bangsa dan negara jangka menengah dan jangka panjang.

Kebijakan pendidikan nasional harus berorientasi dengan kebutuhan nasional masa kini dan masa depan, artinya kebijakan yang diambil harus bervisi masa depan, dengan membaca tantangan masa kini yang semakin kompleks baik segi mutu pendidikan, anggaran pendidikan, pemerataan pendidikan, moral, kompetensi perlu ditingkatkan perhatian, pendidikan yang bermutu akan menghasilkan manusia yang unggul, cerdas, berintegritas dan berkarakter, sebagaimana proyeksi pendidikan abad 21 dikemukakan Anis Rasyid Baswedan ada 3 (tiga) tantang pendidikan yaitu Karakter, Kompetensi, dan Literasi.

Bangsa di masa depan akan mengalami kemajuan pesat di berbagai bidang apabila pendidikan yang dirancang mengutamakan penanaman kekuatan karakter (moral) (character building) berdasarkan nilai-nilai luhur diyakini sebagai cosmologi kehidupan berbangsa, dan berbangsa, di mana ia hidup (living) dalam diri sebagai kekuatan karakter membimbing manusia berbuat adil, jujur, bijaksana dan bertanggung jawab, banyak bangsa hancur karena kehilangan jati diri bangsa, begitupun sebaliknya banyak bangsa yang tangguh karena karakter yang kuat. Bangsa Indonesia memiliki kekayaan karakter yang majemuk karena dihuni oleh banyak suku, etnis, kepercayaan, agama dan adat istiadat, keanekaragaman budaya dimiliki menjadi kekuatan penting dalam mendorong bangsa Indonesia menjadi lebih maju, mandiri dan berdaya saing dengan bangsa lain, apabila pendidikan karakter berbasis nilai-nilai pancasila konsisten dilakukan.

Pendekatan pendidikan selama ini hanya fokus pada penguasaan kecakapan di ranah kognitif yaitu kemampuan dibidang intelektual dan kecakapan ketrampilan di bidang psikomotorik, sedangkan internalisasi nilai-nilai luhur kehidupan bangsa mendapatkan porsi yang tidak seimbang. Pendidikan pancasila sangat menekankan pada aspek afektif yaitu penanaman nilai sikap, dan karakter agar mahasiswa menjadi pribadi yang jujur, bijaksana dan bertanggung-jawab berdasarkan nilai-nilai 
pancasila, internalisasi nilai-nilai pancasila dalam kehidupan berbangsa, bernegara harus betul diterapkan menjadi jati diri bangsa, dalam mewujudkan mahasiswa yang beriman dan bertakwa kepada Tuhan Yang Maha Esa.

STKIP Bima adalah salah satu lembaga pendidikan tinggi swasta yang berada di bawah naungan kementerian pendidikan dan kebudayaan Republik Indonesia yang didirikan pada tahun 1976 di Bima, STKIP Bima dalam perjalanannya telah banyak membantu pemerintah dalam usaha mencerdaskan kehidupan bangsa Indonesia demi terwujudnya masyarakat adil makmur berdasarkan Pancasila dan UUD NRI 1945, sebagai kampus pendidikan tertua di Bima, STKIP Bima telah banyak melahirkan banyak insan cerdas, kompetitif dan berkarakter dalam membangun bangsa Indonesia agar bisa bersaing dengan bangsa.

STKIP Bima juga dalam kurikulum pembelajarannya konsisten mengimplementasikan pendidikan karakter melalui pendidikan pancasila dan kewarganegaraan, ilmu Sosial dan Budaya Dasar dan pendidikan agama islam, yang secara khusus dimaksudkan untuk membangun karakter (character building) mahasiswa STKIP Bima yang jujur, adil, bijaksana, toleran, berbudaya dan bertanggung jawab dengan harapan ketika mahasiswa kembali kepada kehidupan masyarakat mereka menjadi warga Negara yang baik, patuh hukum, dan bertanggung jawab serta mampu menjadi problem solver dalam kehidupan sosial.

Implementasi pendidikan Pancasila di STKIP Bima berdasarkan ketentuan kurikulum nasional sebagaimana diatur dalam Undang-undang No.20 Tahun 2003 pasal 1 bahwa pendidikan nasional berdasarkan pancasila dan pasal 33 Undangundang 12 tahun 2012 tentang Pendidikan Tinggi bahwa struktur pendidikan tinggi wajib mencantumkan Mata Kuliah Dasar Umum diantaranya adalah pendidikan Pancasila dan kewarganegaraan, mata kuliah pendidikan pancasila dari kurikulum pendidikan dikelompok dalam mata kuliah pengembangan kepribadian (MPK).

\section{KAJIAN TEORI}

\section{Hakikat Nilai Pendidikan Pancasila}

Pendidikan Pancasila adalah program pendidikan yang berisi nilai-nilai luhur bangsa yang memiliki tujuan untuk membentuk sikap positif manusia sesuai dengan nilai-nilai yang terkandung dalam Pancasila. Menilai berarti menimbang, yaitu kegiatan manusia menghubungkan sesuatu dengan sesuatu untuk selanjutnya mengambil sebuah keputusan. Keputusan nilai dapat mengatakan "berguna atau tidak berguna, benar atau tidak benar, baik atau tidak baik, religius atau tidak religius". Sesuatu itu dikatakan mempunyai nilai apabila sesuatu itu berguna, berharga (nilai kebenaran), indah (nilai estetis), baik (nilai moral dan etis), religius (nilai agama). Notonagoro 1975 dalam (Zulfikar Putra, 2018: 10) membagi nilai pendidikan Pancasila menjadi tiga bagian yaitu:

a. nilai materil, yaitu segala yang berguna bagi jasmani/unsur fisik manusia;

b. nilai vital, yaitu segala sesuatu yang ber- guna bagi manusia untuk melakukan suatu kegiatan aktifitas;

c. nilai kerohanian, yaitu segala sesuatu yang berguna bagi rohani manuisa yang dibagi menjadi:

1) nilai kebenaran/kenyataan adalah nilai yang bersumber pada unsur akal 
manusia

2) nilai keindahan adalah nilai yang bersumber pada unsur rasa manusia

3) nilai kebaikan atau nilai moral adalah nilai yang bersumber pada unsur kehendak/ kemauan manusia

4) Nilai religious adalah nilai ketuhanan yang tertinggi yang sifatnya mutlak dan abadi.

Perumusan Pancasila sebagaimana termaktub dalam alinea ke-4 Pembukaan UUD 1945 dinyatakan sebagai nilai dasar dan penjabarannya sebagai nilai instrumental. Nilai dasar tidak berubah dan tidak dapat diubah lagi. Nilai-nilai dasar yang terkandung dalam pembukaan UUD 1945 itu memerlukan penjabaran lebih lanjut. Penjabaran itu sebagai arahan untuk kehidupan nyata, penjabaran itu kemudian dinamakan nilai instrumental Pancasila memiliki kedudukan sebagai dasar negara dan ideologi nasional. Diterimanya Pancasila sebagai dasar negara dan ideologi nasional membawa konsekuensi logis bahwa nilai- nilai Pancasila dijadikan landasan pokok atau landasan fundamental bagi penyelenggaraan negara Indonesia (Zulfikar Putra, 2018 :10).

\section{Pembentukan character building mahasiswa}

Istilah karakter dapat diartikan sebagai sistem daya juang (daya dorong, daya gerak, dan gaya hidup) yang berisikan tata nilai kebajikan dan moral yang berpatri dalam diri manusia. Tata nilai itu merupakan perpaduan aktualisasi potensi dari dalam diri manusia serta internalisasi nilai-nilai akhlak dengan moral dari luar (lingkungan) yang melandasi pemikiran, sikap dan perilaku dengan kata lain, karakter adalah nilai kebajikan akhlak dan moral yang terpatri dan menjadi nilai intristik dalam diri manusia yang melandasi pemikiran, sikap dan perilakunya. Dalam terminologi psiko-logi, karakter adalah watak, perangai, sifat dasar yang khas, suatu sifat atau kualitas yang tetap terus menerus dan kekal sehingga bisa dijadikan ciri untuk mengidentifikasikan seseorang (Chaplin, 2008 dalam Zulfikar Putra, 2018:10). Sedangkan Coon (Zubaedi, 2012, hal. 8 dalam Zulfikar Putra, 2018:10) mendefinisaikan karakter sebagai suatu penilaian subjektif terhadap kepribadian seseorang yang berkaitan dengan atribut kepribadian yang dapat atau tidak dapat diterima oleh masyarakat. Karakter merupakan keseluruhan disposisi kodrati dan disposisi yang telah dikuasai secara stabil yang mendefinisikan seorang individu dalam keseluruh- an tata perilaku psikis yang menjadikannya tipikal dalam cara berpikir dan bertindak (Raka et al., 2013) dikutip dalam (Zulfikar Putra, $2018: 10)$

Berpedoman pada Keputusan Dirjen Pendidikan Tinggi No. 43/Dikti/Kep/2006 (Dirjen Pendidikan Tinggi, 2006 dalam Zulfikar Putra, 2018 :11) tentang ramburambu pelaksanaan kelompok mata kuliah pengembangan kepribadian di perguruan tinggi, dan sebagai konsekuensi dalam pengembangan karakter dan kepribadian Beberapa langkah tersebut diuraikan berikut: Pertama, dalam sistem pembelajaran mata kuliah pendidikan Pancasila, senantiasa dibangun perspektif pemantapan materi yang di dalamnya memuat nilai-nilai pembelajaran character building di antaranya adalah tentang nilai-nilai ketuhanan, toleransi, nasionalisme dan lain-lain. Kedua, adanya komitmen bersama bagi para dosen pengampu, bahwa mata kuliah yang diampu memiliki relevansi dengan nilai-nilai character building mahasiswa. Terlebih dengan mata kuliah yang berhubungan langsung dengan character building 
mahasiswa seperti mata kuliah agama, pengantar nilai dan kepribadian serta pendidikan karakter. Ketiga, penyelenggaraan pembelajaran mata kuliah pendidikan Pancasila tidak lagi menggunakan kebiasaan lama yang lebih terkonsentrasi dalam penyampaian materi kognitif dengan waktu yang terbatas, tetapi dikembangkan dengan format pembelajaran yang lebih terbuka dan memberi peluang bagi mahasiswa untuk dapat berinteraksi (berdiskusi/berdialog) dengan dosen pengampu mata kuliah pendidikan Pancasila. Kementerian Pendidikan Nasional (2009, hal. 9-10 dalam Zulfikar Putra, 2018:11) menyebut bahwa pendidikan karakter dikembangkan dari sumber agama, Pancasila, budaya dan tujuan pendidikan nasional. Dari keempat sumber tersebut, maka dihasilkan sejumlah nilainilai pendidikan karakter untuk pendidikan budaya dan karakter bangsa sebagai berikut:

Tabel 1. Nilai dan deskripsi nilai karakter

\begin{tabular}{|c|c|l|}
\hline No & Nilai & \multicolumn{1}{|c|}{ Deskripsi Nilai Karakter } \\
\hline 1 & Relegius & $\begin{array}{l}\text { Sikap memegang teguh perintah agama dan menjauhi } \\
\text { larangan umat beragama satu dengan umat beragama lainnya }\end{array}$ \\
\hline 2 & Jujur & $\begin{array}{l}\text { Sikap yang selalu berpegang teguh untuk menghindari } \\
\text { keburukan dengan menjaga perkataan, perasaan dan } \\
\text { perbuatan untuk selalu berkata benar dan dapat dipercaya }\end{array}$ \\
\hline 3 & Toleransi & $\begin{array}{l}\text { Perilaku cenderung mengahargai perbedaan baik itu sikap } \\
\text { dan tindakan dalam hal mengharagi perbedaan agama, } \\
\text { suku, etnis, pendapat, sikap dan tindakan orang lain yang } \\
\text { berbeda darinya }\end{array}$ \\
\hline 4 & Displin & $\begin{array}{l}\text { Tindakan yang menunjukkan perilaku taat, tertib, teratur } \\
\text { dan patuh kepada ketentuan dan peraturan yang berlaku } \\
\text { sesuai dengan tujuan tertentu }\end{array}$ \\
\hline 5 & Kerja keras & $\begin{array}{l}\text { Perilaku yang menunjukkan upaya yang sungguh-sungguh } \\
\text { untuk menyelesaikan suatu pekerjaan dengan sebaik-baiknya }\end{array}$ \\
\hline 6 & Kreatif & $\begin{array}{l}\text { Upaya mencari alternative penyelesaian permasalahan } \\
\text { dari berbagai sudut pandang }\end{array}$ \\
\hline 8 & Mandiri & $\begin{array}{l}\text { Suatu sikap dan perilaku yang tidak mudah tergantung pada } \\
\text { orang lain dalam menyelesaikan tugas }\end{array}$ \\
\hline 9 & Rasa Ingin & $\begin{array}{l}\text { Daka dahu } \\
\text { dirinya dan orang lain dalam kedudukan yang sama } \\
\text { untuk mengetahui lebih mendalam dan meluas dari sesuatu } \\
\text { yang dipelajari, dilihat dan didengar }\end{array}$ \\
\hline 10 & $\begin{array}{l}\text { Rasa } \\
\text { Kebangsaan }\end{array}$ & $\begin{array}{l}\text { Cara berpikir, bertindak, dan berwawasan yang } \\
\text { menempatkan kepentingan bangsa dan negara diatas } \\
\text { kepentingan diri dan kelompoknya }\end{array}$ \\
\hline
\end{tabular}

Dengan demikian pembentukan nilai-nilai karakter mahasiswa dapat dibentuk dengan sarana pem- belajaran, juga dalam ranah kehidupan ber- masyarakat, berbangsa dan bernegara (Budiningsih, 2004 dalam Zulfikar Putra, 2018 :11).

\section{Implementasi pendidikan Pancasila dalam membentuk character building mahasiswa}


Membentuk character building mahasiswa merupakan instrument penting dalam mewujudkan visi dan misi yang ditentukan oleh pemerintah pada pembangunan nasional yang dijabarkan dalam RPJP 2005-2025, yaitu untuk memajukan generasi penerus dalam menghadapai ancaman dari luar sambil melakukan upaya menjaga keutuhan NKRI dari dalam. Implementasi pendidikan Pancasila dalam membentuk character building membutuhkan keterlibatan semua elemen masyarakat bangsa dari orang tua, dosen, tokoh masyarakat, tokoh ormas dan tokoh agama. Untuk mewujudkan mahasiswa yang ber- karakter baik perlu juga dukungan iklim lingkungan kampus yang baik dan lembaga-lembaga lain di luar kampus untuk memperkokoh kepribadian mahasiswa. Nilai-nilai karakter yang dikembangkan merupakan nilai-nilai yang menjadi pembiasaan dalam kehidupan sehari-hari (Zulfikar Putra, 2018:12).

Pancasila sebagai dasar negara dan ideologi bangsa yang berisi lima sila pada hakikatnya berisi lima nilai dasar yang fundamental (Kementerian Pendidikan Nasional, 2009 dalam Zulfikar Putra, 2018 :12). Pertama, Sila Ketuhanan Yang Maha Esa di dalamnya terkandung nilai-nilai bahwa NKRI bukan sebagai negara agama dan bukan pula sebagai Negara sekuler, tetapi NKRI ingin dikembangkan sebagai negara beragama. Maksud dari bukan sebagai negara agama, bahwa NKRI tidak menerapkan hukum agama tertentu sebagai hukum positif, artinya: 1) ideologi negara tidak berasal dari ideologi agama tertentu; 2) kepala negara tidak harus berasal dari penganut agama tertentu; 3) konstitusi negara tidak dari kitab suci agama tertentu. Maksud dari bukan sebagai negara sekuler, bahwa NKRI tidak memisahkan urusan agama dengan urusan negara artinya: 1) keputusan negara harus didasarkan pada ajaran agama- agama; 2) suara terbanyak dalam lembaga MPR, DPR, dan lain sebagainya harus dilandaskan pada kesesuaiannya dengan ajaran Tuhan Yang Maha Esa. Maksud dari bukan sebagai negara agama bahwa NKRI mendasarkan pengelolaan negara pada hukum positif yang disepakai oleh bangsa (MPR, DPR dengan Pemerintah) yang warga negaranya beragam agama, sementara negara pun tidak boleh mencampuri urusan aqidah agama apapun, tetapi negara wajib melindungi agama apapun.

Kedua, sila Kemanusiaan yang adil dan beradab di dalamnya terkandung nilainilai bahwa NKRI merupakan negara berdasarkan hak asasi manusia (berkemanusiaan), berdasarkan hukum (yang berkeadilan) dan negara berbudaya (yang beradab). Maksud dari negara berdasarkan hak asasi manusia yaitu bahwa NKRI melindungi dan menegakkan HAM bagi warga negaranya. Maksud dari negara berbudaya yaitu bahwa NKRI ingin mengembangkan: 1) cipta, yang dapat melahirkan ilmu pengetahuan dan teknologi; 2) karsa, yang dapat melahirkan moral dan etika; 3) rasa, yang dapat melahirkan seni dan estetika; dan 4) karya, yang dapat melahirkan karya-karya monumental dalam arti yang seluas-luasnya. Sebagaimana diketahui, keempatnya itu merupakan unsur dari budaya.

Ketiga, sila Persatuan Indonesia di dalamnya terkandung nilai-nilai bahwa NKRI menyatakan diri sebagai negara yang diikat oleh persatuan dan kesatuan. Keempat, sila Kerakyatan yang dipimpin oleh hikmat dalam permusyawaratan/perwakilan di dalamnya terkadung makna bahwa NKRI menerapkan asas kerakyatan yang landasan penera- pannya berdasarkan kedaulatan rakyat. Kedalatan rakyat berbasis demokratis dan prinsip-prinsip demokratis bersifat universal. Kelima, sila Keadilan sosial bagi seluruh rakyat Indonesia di dalamnya 
terkandung makna bahwa keadilan sosial atau pemerataan bersama bagi seluruh komponen rakyat Indonesia bukan keadilan bagi segolongan/ pemerintah/penguasa

\section{METODE PENELITIAN}

Penelitian ini merupakan library research yaitu penelitian kepustakaan. Adapun jenis data adalah data sekunder. Teknik pengambilan data dilakukan studi literatur atau analisis dokumen. Penelitian ini menggunakan pendekatan penelitian kualitatif secara deskriptif dengan menerapkan teknik studi dokumentasi. Analisis data hasil penelitian ini dilakukan secara kualitatif yaitu menguraikan data secara deskriptif berdasarkan fakta yang ada.

\section{HASIL DAN PEMBAHASAN}

\section{Implementasi Nilai-Nilai Pendidikan Pancasila di Kampus Stkip Bima}

Implementasi nilai-nilai pendidikan pancasila di STKIP Bima, tentu berdasarkan pada fungsi dan tujuan Perguruan Tinggi yaitu penguasaan ilmu pengetahuan dan teknologi. Penguasaan ilmu pengetahuan dan teknologi bertujuan untuk meningkatkan taraf kehidupan masyarakat. Dengan demikian ada sekurangkurangnya empat atau lima dimensi makna yang melekat pada perguruan tinggi, yaitu (1) dimensi keilmuan (ilmu dan teknologi), (2) dimensi pendidikan (pendidikan tinggi), (3) dimensi sosial (kehidupan bermasyarakat), dan (4) dimensi korporasi (satuan pendidikan atau penyelenggara). Dari keempat dimensi tersebut di atas apabila pendidikan tinggi dimaksudkan untuk meningkatkan martabat manusia, maka dapat diangkat ke dalam dimensi makna yang lebih mendalam, yaitu (5) dimensi etis, (R.Eko Indrajit dan R.Djokoprapnoto, 2006:3-4).

Kelima dimensi makna perguruan tinggi tersebut bagi penulis penting diuraikan satu persatu, supaya mudah dipahami dan telaah tentang pentingnya implementasi 5 (lima) dimensi dalam penyelenggaran pendidikan tinggi dalam rangka meningkatkan martabat manusia yang memiliki kepribadian jujur, santun, adil, bijaksana, toleran, bekerja sama dan bertanggung jawab. Adapun Kelima dimensi makna pendidikan tinggi menurut R.Eko Indrajit dan R.Djokoprapnoto, 2006:36 adalah sebagai berikut :

1. Dimensi Etis

Universitas dikenal sebagai pusat kreatifitas dan pusat penyebaran ilmu pengetahuan bukan demi kreatifitas sendiri tetapi demi kesejahteraan umat manusia. Hakekat tugas dan panggilan universitas ialah mengabdikan diri pada pengajaran, penelitian, dan pendidikan para mahasiswa yang dengan suka bergabung dengan para dosen dalam cinta yang sama akan pengetahuan. Universitas adalah suatu komunitas akademik yang cermat dan kritis membantu melindungi dan meningkatkan martabat manusia atau warisan budaya melalui peneliitian, pengajaran, dan berbagai pelayanan yang diberikan kepada komunitas setempat, nacional, dan bahkan internacional. Unversitas bergumul dalam pencarian akan kebenaran secara terus menerus dan mengkomunikasikannya kepada kaum muda dan kepada siapapun yang belajar berpikir, sehingga dapat secara benar bertindak dan melayani umat manusia dengan lebih baik. Di dalam konteks pencarian kebenaran secara utuh, 
universitas mempunyai kebebasan akademik. Kebebasan akademik berakar pada martabat manusia yang mempunyai kebebasan internal atau kebebasan dasar dalam pribadinya. Namun, di sisi lain, tidak dapat tidak manusia harus mencari makna penemuan baru. Makna tersebut akan menjamin bahwa penemuan baru digunakan untuk kesejahteraan otentik individu dan masyarakat secara keseluruhan. Di sini terasa kekentalan dimensi moral dan etis penemuan ilmu penegtahuan dan teknologi. Peran universitas pada perlindungan martabat manusia serta pada tanggung jawab moral penemuan ilmu pengetahuan dan teknologi adalah beberapa contoh dimensi etis dari makna perguruan tinggi.

2. Dimensi Keilmuan

Dunia perguruan tinggi adalah dunia ilmu pengetahuan. Tujuan utama pendidikan tinggi adalah mengembangkan dan menyebarkan ilmu pengetahuan, teknologi, dan kebudayaan dengan proses belajar mengajar, penelitian, dan pengabdian kepada masyarakat. Hanya di perguruan tinggi melalui pendidikan tinggi ilmu pengetahuan betul-betul dikembangkan dan bahkan bukan di pendidikan yang lebih rendah atau di tempat lain. Universitas adalah suatu masyarakat akademik, yaitu masyarakat ilmu penegtahuan yang mempunyai otonomi ilmu pengetahuan berupa kebebasan akademik dalam tiap displin ilmu pengetahuan sesuai dengan prinsip dan metode masing-masing. Oleh karena itu, para dosen harus berusaha selalu meningkatkan kompetensi di bidang ilmu penegtahuan dan penelitian yang dikusainya. Demikian pula, para mahasiswa dirangsang untuk secara kritis, sistimatis, dan taat asas serta mau dan mampu belajar seumur hidup.

3. Dimensi Pendidikan

Pendidikan tinggi adalah pendidikan, yaitu pendidikan pada tingkat tinggi. Namun, hal ini sering menimbulkan polemik apakah memang betul bahwa proses yang terjadi di perguran tinggi merupakan suatu pendidikan atau suatu pembelajaran karena arti "pendidikan" lain sama sekali dengan "pembelajaran". Dalam proses pembelajaran, mahasiswa diusahakan menjadi yang belajar, mau belajar terus-menerus. Proses pembelajaran umumnya bersifat formal. Sebaliknya, pendidikan adalah penyiapan manusia muda menjadi manusia dewasa, yaitu manusia yang mandiri dan bertanggung jawab. Proses pendidikan bersifat informaldan terjadi terutama di dalam keluarga, tetapi dapat pula terjadi di daam masyarakat dan sekolah. Dalam proses pendidikan termasuk pendidikan tinggi, tidak ada pengaturan, kurikulum maupun penjenjangan.Pokoknya, tidak ada struktur atau sistem yang ada adalah penjenjangan, pentauran, perencanaan, struktur dan sisem mengenai pembelajaran. Namun, polemik mungkin dapat didamaikan dengan penjelasan bahwa dalam perguruan tinggi terjadi pendidikan melalui pembelajaran. Pendidikan dapat diberikan, baik dalam kurikulum intra, kurikulum ekstra, maupun kurikulum tersembunyi. Dalam kurikulum intra, pendidikan dapat diberikan dalam bentuk penjelasan dan contoh aplikasi ilmu pengetahuan. Dalam kurikulum ekstra pendidika dapat diberikan dalam seni budaya, seni olahraga, dan seni organisasi dan sebagainya. Kemudian, dalam kurikulum tersembunyi, pendidikan dalam dapat diberikan dalam contoh nyata pengaturan dan pengelolaan universitas. Displin, keterbukaan, pelayanan, bantuan, pada yang lemah, kejujuran, kerja keras, dan sebagainya yang 
diperlihatkan dalam pengelolaan universitias atau perguruan tinggi adalah nilainilai konkret yang merupakan contoh nyata untuk pendidikan.

4. Dimensi Sosial

Penemuan ilmiah dan penemuan teknologi telah menciptakan pertumbuhan ekonomi dan industri yang sangat besar. Melalui pertumbuhan ekonomi dan industri, kesejahteraan manusiapun ditingkatkan. Melalui kegiatan dan perjuangan para ahli dan mahasiswa, kehidupan demokrasi ditingkatkan dan martabat manusia lebih dihargai. Perguruan tinggi mempersiapkan para mahasiswa untuk mengambil tanggung jawab di dalam masyarakat. Dari para lulusannya, masyarakat mengharapkan pembaruan dan perbaikan terus-menerus dalam tata kehidupan bermasyarakat dan bernegara. Lebih lajut, melalui pengajaran dan penelitian perguruan tinggi diharapkan memberikan sumbangan dalam memecahkan berbagai problema yang sedang dihadapi masyarakat seperti kekurangan pangan, pengangguran, kekurangan pemiliharaan kesehatan, ketidakadilan dan kebodohan dan sebagainya.

5. Dimensi Korporasi

Perguruan tinggi memberikan jasa kepada msyarakat berupa pendidikan tinggi dalam bentuk proses belajar mengajar dan penelitian. Yang diajarkan dan diteliti adalah ilmu pengetahuan. Perguruan tinggi mempunyai pelanggan, yaitu para mahasiswa dan masyarakat pengguna lulusan. Perguruan tinggi menghadapi persaingan antar perguruan tinggi lain, baik dari dalam maupun dari luar negeri. Apabila mahasiswa (pelanggan) perguruan tinggi terlalu sedikit, perguruan tinggi tidak membiayai dirinya sendiri, sehingga mengalami defisit dan kalau terus menerus demikian, kelangsungan hidupnya akan terancam. Ada semacam break even point yang harus dicapai dalam penyelenggaran perguruan tinggi. Perguruan tinggi memiliki dan mengelola berbagai sumber daya seperti manusia, barangbarang, perlatan, keuangan dan metode. Perguruan tinggi perlu memperkenalkan produksinya pada masyarakat agar dikenal dan dibeli. Semua dimensi di atas tidak terpisah secara ketat, tetapi saling berhubungan, saling menunjang, saling mempengaruhi..

Keberadaan perguruan tinggi sangat dibutuhkan sebagai tempat untuk menumbuhkan segala kreatifitas, meningkatkan kompetensi pengetahuan dan melatih kemampuan akademik dan kemampuan sosial agar mahasiswa memiliki hardskill dan softskill sebagai bekal memasuki dunia kerja dan kehidupan sosial yang serba serbi tantangannya, sehingga memerlukan lifeskill yang mumpuni agar mampu bertahan dan bersaing dengan ketatnya kompetisi yang mengutamakan kompetensi di mana kompetensi menjadi jurus selamat yang memberikan tuah bagi generasi milinea yang mengutamakan mengusai IPTEKS, dan memiliki karakter yang khas seperti mental yang tangguh, displin, kerja keras, mandiri, pantang menyerah,bersikap ramah, sopan santun, toleransi dan anti kekerasan.

STKIP Bima adalah salah satu lembaga pendidikan tinggi sebagai tempat berkembang dan tumbuhnya ilmu pengetahuan dan teknologi memiliki komitmen untuk membantu pemerintah dalam rangka mencerdaskan kehidupan bangsa sebagaimana amanat UUD NRI Tahun 1945, oleh karena itu STKIP sesuai dengan visi-misinya yaitu mencetak tenaga pendidik dan tenaga kependidikan yang profesional, terlatih dan siap dipakai, visi-misi tersebut menggambarkan 
komitmen dan konsistensi STKIP untuk melahirkan alumni yang memiliki karakter kepribadian yang mencerminkan mahasiswa calon guru yang profesional dengan memiliki 4 (empat) kompetensi utama sebagai penjabaran lebih spesisik kompetensi guru, tentunya penguasaaan kompetensi sangat didukung oleh sarana dan prasarana pendidikan.

\section{Pelaksanaan Nilai-Nilai Pendidikan Pancasila dalam Kegiatan Kurikuler, Ko Kurukuler dan Ekstra Kurikuler Di Kampus Stkip Bima}

Bahwa implementasi nilai-nilai pendidikan Pancasila di Kampus STKIP Bima, baik melalui kegiatan pembelajaran formal sebagaimana yang diamanat dalam kurikulum nasional, bahwa pendidikan nasional berdasarkan Pancasila dan UndangUndang Dasar Negara Republik Indonesia tahun 1945 (UU No.20 Tahun 2003), maupun penjelasan lebih operasional tentang implementasi pendidikan pancasila sebagai mata kuliah wajib yang diajar di seluruh pendidikan tinggi negeri, swasta, agama dan umum diatur dalam pasal 35 ayat 3 Undang-undang Nomor 12 Tahun 2012 yang berbunyi : Bahwa kurilkulum pendidikan tinggi wajib memuat mata kuliah pendidikan agama, pendidikan pancasila, pendidikan kewarganegaraan dan bahasa Indonesia. Ayat 4 Kurikulum pendidikan tinggi dilaksanakan melalui kegiatan kurikuler, kokurikuler, dan ekstrakurikuler.

STKIP Bima merupakan kampus pendidikan yang menyelenggarakan kegiatan tri dharma perguruan tinggi yaitu kegiatan pengajaran, penelitian dan pengabdian, STKIP Bima juga dalam rangka beradaptasi dengan kemajuan jaman dan perubahan perkembangan ilmu pengetahuan dan teknologi terus melakukan perubahan kebijakan pendidikan mulai dari desain perubahan kurikulum, perubahan visi-misi dengan harapan kampus bisa adaptasi dengan inovasi kebaruan menuju kampus unggul, berkarakter dan kompetitif.

STKIP Bima memiliki tujuh program studi yang terdiri dari Program Studi Pendidikan Ekonomi, Pendidikan Biologi, Pendidikan BK, Pendidikan Matematika, Pendidikan Sosiologi, Pendidikan Kimia, Pendidikan Fisika. Setiap program masingmasing memiliki karakteristik muatan materi kurikulum, mata kuliah pendidikan Pancasila dimasukkan dalam kelompok Mata Kuliah Pengembangan Kepribadian (MPK). Mata kuliah pendidikan Pancasila diberikan di semester 1 (satu) dengan tujuan memantapkan kepribadian mahasiswa agar mereka menjadi pribadi yang beriman dan bertakwa kepada Tuhan YME, dengan sikap dan perilaku memiliki kemampuan untuk bersikap bertanggung jawab, memiliki kemampuan untuk mengenali perubahan dan perkembangan jaman dan Ipteks, memiliki kemampuan bersikap untuk menggalang persatuan demi keutuhan bangsa.

Mata kuliah pendidikan Pancasila sebagai mata kuliah wajib sangat berperan sekali membentuk karakter mahasiswa yang patuh pada hukum dengan harapan mereka dapat menjadi warga Negara yang baik dan menjadi pelopor perubahan bagi masyarakat, ketika mereka kembali kedalam kehidupan sosial kemasyarakatan, karena fungsi mahasiswa sebagai agen of change diharapkan menjadi problem solver untuk menciptakan banyak perubahan dan perbaikan kualitas hidup.

Implementasi nilai-nilai pendidikan Pancasila di STKIP Bima tidak saja dilakukan melalui kegiatan kurikuler semata, tetapi juga dilaksanakan melalui kegiatan kokurikuler dan ekstra kurikuler, pelaksanaan nilai-nilai pendidikan pancasila di STKIP Bima dapat dijelaskan sebagai berikut : 
1. Sosialisasi Kegiatan PKKMB

Pada saat kegiatan PKKMB mahasiswa Baru semua mahasiswa diwajibkan mengikuti kegian sosialisasi wawasan kebangsaan untuk menumbuhkan semangat cinta tanah air dan toleransi untuk mewujudkan mahasiswa calon pemimpin masa depan yang bertakwa kepada Tuhan Yang Maha Esa. Dan memiliki jiwa patriotik dan bijaksana. Kegiatan PKKMB diselenggarakan sebelum mahasiswa melaksanakan kegiatan perkuliahan, dengan melibatkan unsur TNI, Polri, Praktisi, akademisi dan Ormawa.

2. Melalui Pendidikan

Dosen pengampu mata kuliah pendidikan Pancasila diberikan tugas sebelum memulai kegiatan perkuliahan, diminta untuk menyiapkan materi pembelajaran yang content materinya betul-betul mengarahkan pada usaha pembentukan karakter mahasiswa berdasarkan Pancasila, yaitu menghasilkan mahasiswa yang beriman dan bertakwa kepada Tuhan Yang Maha Esa.

3. Melalui Kerjasama

STKIP Bima dalam rangka memantapkan karakter mahasiswanya menjalin kerjasama dengan perguruan tinggi baik tingkat lokal maupun perguruan tinggi di tingkat nasional, dengan tujuan antara perguruan tinggi dapat melibatkan mahasiswa dalam kegiatan tri dharma perguruan tinggi, seperti kegiatan pertukaran mahasiswa KKN antara perguruan tinggi.

4. Melalui pembinaan Kegiatan ko kurikuler dan ekstrakurikuler

STKIP Bima dalam rangka mengasah bakat dan minat mahasiswa yang memiliki skill dan life skiil menyediakan wadah untuk menghimpun potensi kreatif mahasiswa seperti oganisasi HMPS, HMJ, LDK, Mapala Londa, Gong 96, Pramuka.

\section{KESIMPULAN}

Implementasi nilai-nilai pendidikan pancasila di STKIP Bima dilaksanakan melalui kegiatan kurikuler, kokurikuler dan ekstra kurikuler dalam rangka memantapkan kepribadian mahasiswa agar menjadi pribadi yang beriman dan bertakwa kepada Tuhan Yang Maha Esa dengan sikap dan perilaku jujur, adil, bijaksana dan bertanggung jawab berdasarkan nilai-nilai pancasila yaitu Ketuhanan Yang Maha Esa, Kemanusiaan Yang Adil beradab, dan menjunjung tinggi nilai persatuan.

\section{DAFTAR PUSTAKA}

Andang, (2014). Kebijakan Kurikulum Reorientasi Pendidikan Nasional Melalui Implementasi Kebijakan Kurikulum 2013. UMM Press Malang.

Kemendikbud, (2012). Pengembangan Kurikulum 2013. Strategi Implementasi Kurikulum 2013.

Kurikulum Program Studi di Lingkup STKIP Bima

Peraturan Akademik di Lingkup STKIP Bima.

R.Eko Indrajit dan R.Djokoprapnoto (2006). Manajemen Pendidikan Tinggi. Andi Yogjakarta. 
Samani dan Hariyanto. (2012). Konsep dan Model, Pendidikan Karakter. CV. Andi Offset. Yogjakarta.

Undang-undang No.12 Tahun 2012 Tentang Pendidikan Tinggi

Undang-Undang No.20 Tahun 2013 Tentang Sistem Pendidikan Nasional

Zulfikar Putra a,1* Jurnal Citizenship: Media Publikasi Pendidikan Pancasila dan Kewarganegaraan. 